\title{
Collaboration between Regencies in Fulfilling The National Production Of Rajangan Madura Tobacco
}

\author{
Dzikrillah Thoriqur Rahman $^{1 *}$, Retno Sunu Astuti \\ Public Administration, FISIP, Universitas Diponegoro \\ Email: dzikrillahthoriqur.rahman@gmail.com \\ Email: retnosunu@gmail.com
}

(Received: June 8-2020; Revised: September 12-2020; Published: December 31-2020)

\begin{abstract}
This study tries to analyze the concept of inter-regency in the fulfillment of the national production of Madura shredded tobacco and study the factors that cause the decline in Madura sliced tobacco production. Problems that arise at the time of production as well as the area of agricultural tobacco in each district besides the instability of tobacco prices which causes anxiety for farmers. To discuss this problem, reference theory from Wright (1974) in Irawanto et al. 2015: 20) there are five key elements in the implementation of intergovernmental relations, i.e. 1) the role of government, 2) interaction of public officials, 3) sustainability communication, 4) the role of administrators, and 5) focus of attention on policy. Data collected through observation, interviews (FGD) and literature study and analyzed qualitatively descriptive. This study represents collaboration between districts which has shown good collaboration by dividing the roles of each region. Interaction of public officials has proven participation in interactions, beliefs, perceptions and preferences. With regard to communication developed from four regions looking for ways and solutions to increase Madura tobacco production and avoid the volatility of Madura shredded tobacco prices in the harvest season. This collaboration has a target of achieving fulfillment of Madura Chopped Tobacco Production, increasing thirty percent from Madura Tobacco Production annually targeting eighty tons.
\end{abstract}

Keywords: Collaboration, Fulfillment of National Production, Rajangan Madura Tobacco, Farmers

\section{INTRODUCTION}

The State of Indonesia is an archipelago that has a diversity of populations and cultures. From the historical record of the State of Indonesia also known as residents who earn in the field of agriculture, the breadth of the mainland of Indonesia from Sabang to Merauke, from the island ofiangas to the island of Rote reaching $1,919,440 \mathrm{~km} 2$. Of the land area of Indonesia which generally reaches $1,919,440 \mathrm{~km} 2$, it is used for the development of the City/Regency area, housing for residents, industry, agriculture and others.

Indonesian agriculture according to data from the Ministry of Agriculture's Pusdatin in 2014 stated that the area of agricultural land at that time reached 43.5 million hectares with 10.1 million hectares of rice fields, Tegal/Kebun 12.9 million, 6.25 million hectares of rice fields and temporary land that was not being processed 14.25 Million Ha, then the area of agricultural land in Indonesia has taken a portion of $23 \%$ of the land area in Indonesia. The existence of the data above is not surprising if this Indonesian country ranks 6 (six) as a tobacco producer with land area reaching $195,620 \mathrm{Ha}$. With a total tobacco production of 230,000 tons / year. Indonesian tobacco products are able to contribute $2.67 \%$ of tobacco leaves from global supply. The tobacco industry also contributes to state revenues of Rp. 148 Trillion, that number reached $8.92 \%$ of the total APBN in 2018. The following are Indonesian Tobacco data from some of the largest tobacco producing provinces in Indonesia. 


\section{Jurnal Ilmiah Ilmu Administrasi Publik: Jurnal Pemikiran dan Penelitian Administrasi Publik \\ Volume 10 Number 2, July-December 2020. Page 497-507}

\section{Diagram 1}

TEMBAKAU INDONESIA

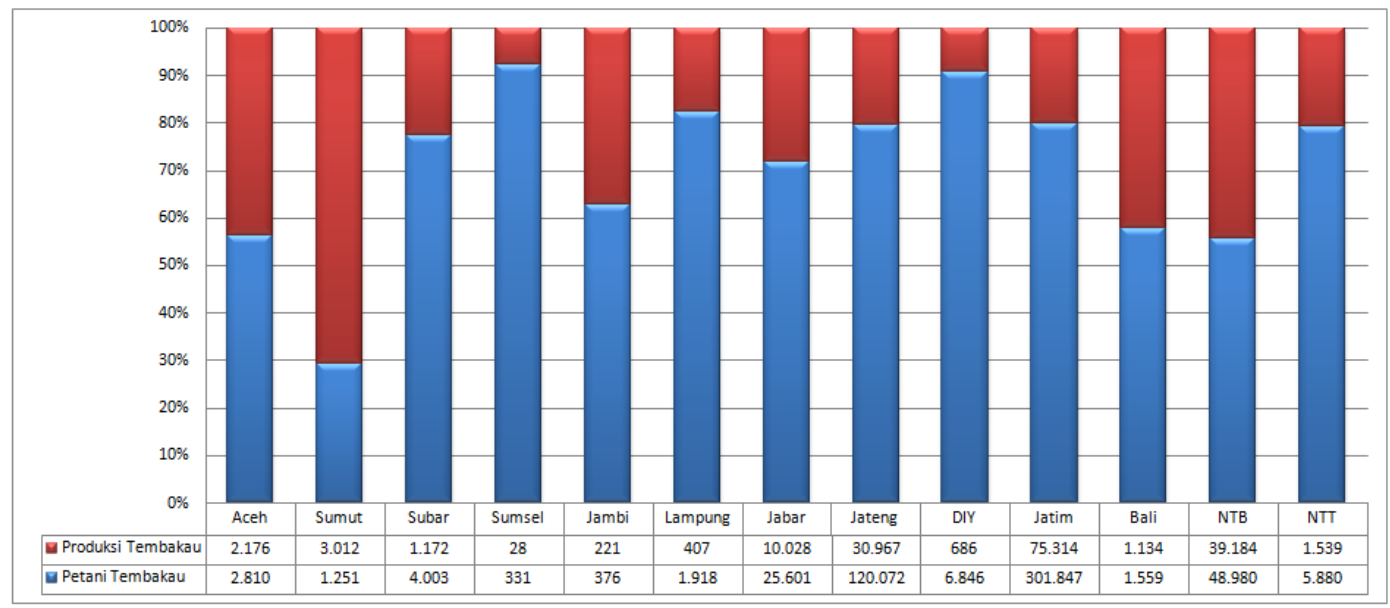

Sumber : https://komunitaskretek.or.id

From the data above shows that tobacco production and the largest number of tobacco farmers in Indonesia is East Java Province where the number of tobacco farmers is 301.847 people with an area of land reaching 91,6241 hectares and the total production produced in each year is 75,314 tons of tobacco. The total amount of abundant production does not escape the participation of districts that are widespread in the East Java region there are about 29 districts. However, not all districts are tobacco producers. Following are the data of the 10 biggest tobacco producing districts in East Java Province in the period of ten years from 2006 to 2015.

Table 1

Tobacco Producing District in East Java

\begin{tabular}{|c|l|c|c|c|c|c|c|c|c|c|c|c|}
\hline \multicolumn{2}{|c|}{ Kabupaten/Kota } & $\begin{array}{c}\mathbf{2 0 0 6} \\
\text { (Ton) }\end{array}$ & $\begin{array}{c}\mathbf{2 0 0 7} \\
\text { (Ton) }\end{array}$ & $\begin{array}{c}\mathbf{2 0 0 8} \\
\text { (Ton) }\end{array}$ & $\begin{array}{c}\mathbf{2 0 0 9} \\
\text { (Ton) }\end{array}$ & $\begin{array}{c}\mathbf{2 0 1 0} \\
\text { (Ton) }\end{array}$ & $\begin{array}{c}\mathbf{2 0 1 1} \\
\text { (Ton) }\end{array}$ & $\begin{array}{c}\mathbf{2 0 1 2} \\
\text { (Ton) }\end{array}$ & $\begin{array}{c}\mathbf{2 0 1 3} \\
\text { (Ton) }\end{array}$ & $\begin{array}{c}\mathbf{2 0 1 4} \\
\text { (Ton) }\end{array}$ & $\begin{array}{c}\mathbf{2 0 1 5} \\
\text { (Ton) }\end{array}$ & $\begin{array}{c}\text { Total } \\
\text { Produksi }\end{array}$ \\
\hline $\mathbf{1}$ & Pamekasan & 10.805 & 16.561 & 17.057 & 12.270 & 10.242 & 16.688 & 19.236 & 3.642 & 15.018 & 13.940 & 135.459 \\
\hline $\mathbf{2}$ & Jember & 364 & 452 & 7.668 & 7.620 & 7.235 & 15.846 & 31.284 & 18.297 & 19.939 & 18.511 & 127.216 \\
\hline $\mathbf{3}$ & Probolinggo & - & - & 13.427 & 11.691 & 9.805 & 7.835 & 10.336 & 9.528 & 13.098 & 12.160 & 87.880 \\
\hline $\mathbf{4}$ & Bojonegoro & 333 & 855 & 7.732 & 10.427 & 3.857 & 15.218 & 11.216 & 5.292 & 9.210 & 8.550 & 72.690 \\
\hline $\mathbf{5}$ & Sumenep & - & - & 13.210 & 6.575 & 3.139 & 9.247 & 13.392 & 3.230 & 9.430 & 8.755 & 66.978 \\
\hline $\mathbf{6}$ & Sampang & 12.989 & 20.029 & 5.880 & 5.908 & 5.670 & 3.002 & 2.702 & 2.202 & 2.896 & 2.689 & 63.967 \\
\hline $\mathbf{7}$ & Situbondo & 10.171 & 8.631 & 1.224 & 3.725 & 4.920 & 7.488 & 8.856 & 2.287 & 5.015 & 4.656 & 56.973 \\
\hline $\mathbf{8}$ & Lamongan & 38 & - & 2.876 & 1.471 & 2.053 & 7.331 & 13.704 & 4.856 & 7.053 & 6.548 & 45.930 \\
\hline $\mathbf{9}$ & Bondowoso & 954 & 1.330 & 4.323 & 5.339 & 3.736 & 7.440 & 4.123 & 5.607 & 4.967 & 4.611 & 42.430 \\
\hline $\mathbf{1 0}$ & Jombang & 339 & 595 & 2.231 & 4.065 & 604 & 2.401 & 4.519 & 4.740 & 7.110 & 6.601 & 33.205 \\
\hline
\end{tabular}

Source: The data is processed from BPS East Java 2015 
Dzikrillah Thoriqur Rahman, Retno Sunu Astuti; Collaboration between Regencies in ... |499

The data above shows the largest tobacco producing center in East Java Province is the island of Madura. In the table above the top ranking of the largest tobacco producers is Pamekasan with a total production of ten years of 135,459 tons. If calculated the total annual production of tobacco farming in Pamekasan District produces 16 tons per year. Large production does not escape the role of farmers in working on agricultural land and maintaining the quality of tobacco, this triggers good economic growth in agriculture in Madura.

Tobacco production on the island of Madura sometimes decreases due to various obstacles, if a decrease in production occurs will lead to scarcity of tobacco and cause a reduction in cigarette factory production. The decline in Madura chopped tobacco production has caused Pamekasan District to take concrete steps to establish cooperation with regencies in Madura, such as Bangkalan, Sampang and Sumenep Regencies to bring the heyday of Madura tobacco back. Through the Regional Coordinating Board (BAKORWIL) based in Pamekasan Regency, the concept of collaboration between the districts was discussed and the objectives delivered. In building cooperation in the field of agriculture will contribute well to each region, especially on the fate of tobacco farmers, with collaboration between districts will boost the welfare of tobacco farmers and there will be a legal umbrella that provides clarity from production to the Madura tobacco trading system. It is undeniable that of the four districts in Madura which have clear regulations on Madura tobacco, only Pamekasan Regency. The existence of this regulation will give an example to other districts to bind the tobacco farmers to existing regulations, so that farmers' rights are protected by the local government.

Diagram 2

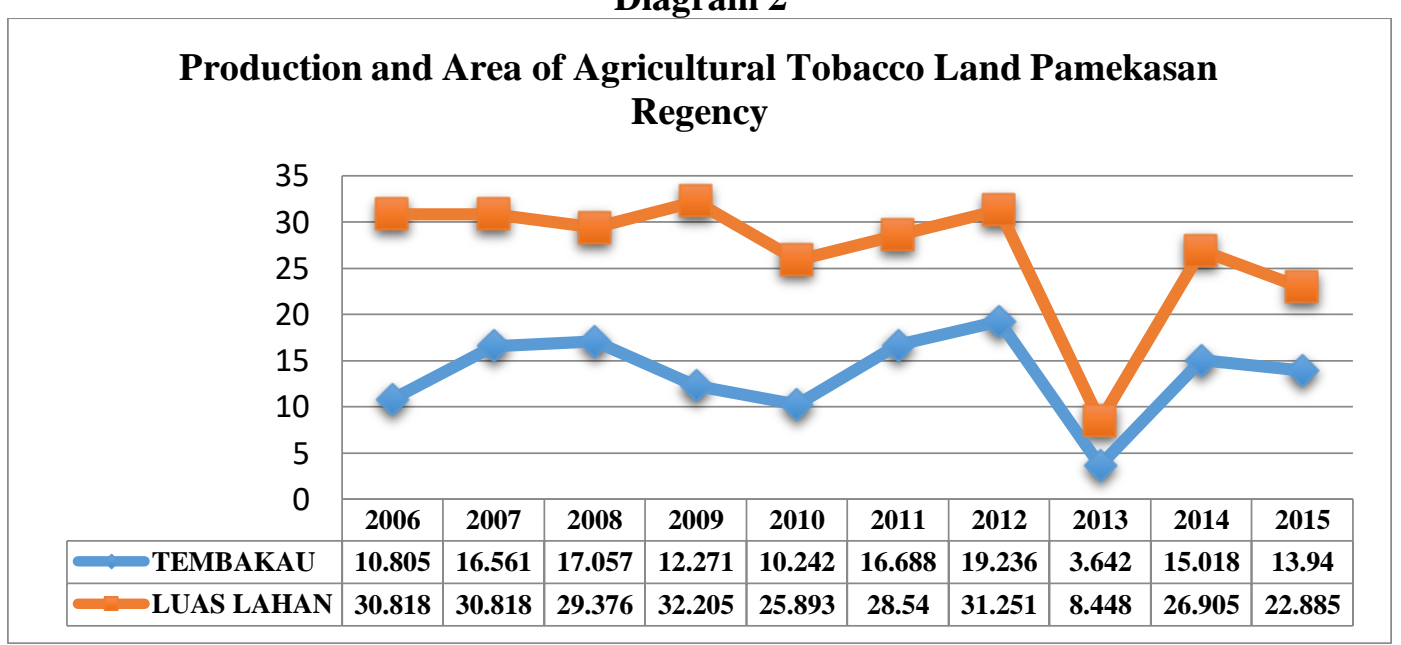

Source: Data Processed by BPS Pamekasan Regency 2016

The diagram above is presented to see the fluctuations in production and land area of Pamekasan Regency which is currently still the largest contributor to Madura or East Java. Analyzing the production and area of Madur Tobacco Farming in Pamekasan Regency, after looking for the causes of the decline in tobacco production and farming area, it turns out that the influence of weather is a major factor in the failure of tobacco harvests, in addition in 2013 Pamekasan Regency tried their luck by planting sugar cane. To be able to expand profits in 


\section{0 | Jurnal Ilmiah Ilmu Administrasi Publik: Jurnal Pemikiran dan Penelitian Administrasi Publik \\ Volume 10 Number 2, July-December 2020. Page 497-507}

agriculture, it's just that it swallowed a failure, where a lot of sugarcane land that failed because of incompatibility of soil structure and a lot of sugarcane land that was burned because of the dry season easily sparked sparks on dry peatlands such as sugar cane land. These factors add to the loss in agriculture for the Pamekasan district government.

So the rate of decline in production from 2012, which started with tobacco production, was 19,236 tons with a land area of 31,251 days and fell in 2013 of around $70 \%$ with a production rate of 3,642 tons with tobacco farms at that time only 8,448 hectares.

Problems began to emerge in the Madura tobacco agriculture sector, data from the table and graph above explain the decline in production experienced by the four districts on the island of Madura, this would reduce the supply of tobacco in terms of Indonesian cigarette production. Yet according to data from the Ministry of Industry the market demand for tobacco reaches 300,000 tons per year that number will continue to grow according to the market's wishes. While Indonesia's agricultural production only reaches 200,000 - 230,000 tons per year. This decline in production will force the central government to continue importing tobacco, if tobacco import policies are implemented every year it will adversely affect the authenticity of Indonesian tobacco and affect the local tobacco market value.

Regional cooperation from the four districts on the island of Madura must be synergized in terms of Madura tobacco farming to meet market needs. Considering Madura tobacco is the best variant in terms of aroma and taste, every district on Madura island must work together and provide policies for tobacco farmers to increase their production.

Law 23 of 2014 concerning Regional Government also provides opportunities for districts / cities to collaborate with districts / cities, provinces and centers. Not all resources needed by regions in developing or organizing public services are owned by regions, therefore regions need other regions to produce what they want. There are limitations to the public expenditure budget in an area so that if one region with another region has the same goal, cooperation is the answer to efficiency in the use of local budgets. These things make the region concerned feel the need to coordinate and cooperate in the implementation and efforts to achieve some regional desires that arise.

The regulation is a supporter of the collaboration between Madura regencies in fulfilling Madura Tobacco Production in order to be able to contribute abundant production and to meet the desires of the national market.

To answer the problems studied and answer the question "to what extent is the discussion of collaboration between districts in meeting the national production of Madura sliced tobacco?". To answer this question, researchers use the theory According to Wright (1974) in (Irawanto et.al, $2015 ; 20)$, there are 5 key elements in the implementation of Intergovernmental Relations namely:

1. The roles of government

This focus stresses on the IGR included as an appropriate object for studying all permutations and combinations of relationships between government units. Government units consist of national, states, counties, municipalities, special districts dan school districts.

2. The interactions of public officials

This second element means that there is no relationship between governments but only relations between officials from different government units. Interaction is observed through 
Dzikrillah Thoriqur Rahman, Retno Sunu Astuti; Collaboration between Regencies in ... $\mid 501$

four sub-elements, namely, attitudes, beliefs, perceptions, and preferences of the personnel involved.

3. Sustainability communication

The third idea implicit in the IGR is that relations are not one-time, occasional occurrences, formally ratified in agreements or rigidly determined by law or court decisions. In contrast, IGR is a pattern of contact, knowledge, and evaluation of government officials that is continuous from day to day. The main concern is informal and formal practices and principles, pursued in a competitive and cooperative interactive pattern.

4. The roles administrators

Intergovernmental relations emphasize the important role played by all public officials involved in cooperation such as elected officials and appointed administrators. The designated administrators are public officials who are appointed both from public authorities and authorities with special / professional functions. While the elected officials consist of officials from the executive, legislative and judicial branches.

5. Focus attentions on the policy

This focus will look at how far the attention of the government towards the cooperation carried out can affect general policy, especially in terms of fiscal policy. In this case, there must be in-depth attention to the impact of the local budget, especially from sub-elements such as financial problems (budgetary capacity), political support, and their impact on other policy areas.

Researchers use this theory because the theory revealed by Wright (1974) is very appropriate to measure the key to success of collaboration (cooperation) between governments (districts). Measuring the key to success of Intergovernmental Relations is strived to provide an evaluation of the way in which collaboration is built together. An evaluation of the collaboration will minimize the success of the program.

\section{METHODS}

This researcher uses a qualitative, research process to solve human (social) problems by explaining information from complete information and organizing it in scientific settings (Nasir, 2012: 34). The research design uses a descriptive style that gives a picture of being trapped in the phenomena taken. The descriptive style was chosen because the researcher described and analyzed "Collaboration between Regencies in Fulfilling the National Production of Rajangan Madura Tobacco".

Sources of data in this study were obtained from literature studies or other information material related to the problem. This research was conducted on Madura Island where Madura Island consisted of four districts including a) Bangkalan Regency, b) Sampang Regency, c) Pamekasan Regency, and d) Sumenep Regency. Of the four regencies in Madura Island, the researchers focused their research on Pamekasan Regency. The selection of this location was based on the concept of collaboration in fulfilling the national production of Madura shredded tobacco held at the Regional Coordinating Board (BAKORWIL) 16-20 tons per year.

Data collection techniques used in this study are as follows: (1) Observation, is the activity of collecting certain things to find something needed in accordance with winning. (2) Interview is a conversation between two or more people aimed at getting the right and reliable information. 


\section{Jurnal Ilmiah Ilmu Administrasi Publik: Jurnal Pemikiran dan Penelitian Administrasi Publik \\ Volume 10 Number 2, July-December 2020. Page 497-507}

(3) Literature study is all conducted by researchers to gather information relevant to the topic or problem to be or is being studied. Information can be obtained from scientific books, research, scientific essays, theses and dissertations, regulations, provisions, annual books, encyclopedias, and written sources both print and electronic. Furthermore, to measure the validity of the data using data triangulation techniques, receiving data reduction, data presentation, and completing conclusions (verification) (Miles, Huberman, and Saldana, 2014).

\section{RESULT AND DISCUSSION}

Madura Island is an island located in the area of East Java Province with an area of 5,200 $\mathrm{km}^{2} \mathrm{~km} 2$, coordinate point $7^{\circ} 0^{\prime} \mathrm{S} 113^{\circ} 20^{\prime} \mathrm{E}$, while the population reaches $3,647,000$ people. Madura Island is known as a salt island, where its name is pinned because Madura Island is the largest salt producer in Indonesia since the Dutch colonial era until now and is not only big in salt production but Madura Island is also the largest tobacco producer in East Kalimantan. Java and the biggest contributor. in national production every year.

The island is divided into four districts. With an area of 1,144 to Bangkalan, $75 \mathrm{~km}^{2}$ is divided into 8 districts, Sampang Regency has an area of $1,321.86 \mathrm{~km}^{2}$, is divided into 12 districts, Pamekasan Regency has an area of $844.19 \mathrm{~km}^{2}$, which is divided into 13 districts, and Sumenep Regency has a total area of $1,857.530 \mathrm{~km}^{2}$, divided into 27 districts spread on land and islands.

Table 2

Madura is divided into four districts :

\begin{tabular}{cccc}
\hline Districts & $\begin{array}{c}\text { Capital } \\
\text { City }\end{array}$ & Area & $\begin{array}{c}\text { Population } \\
\mathbf{2 0 1 5}\end{array}$ \\
\hline $\begin{array}{c}\text { Bangkalan } \\
\text { District }\end{array}$ & Bangkalan & 1,260 & 907,255 \\
\hline $\begin{array}{c}\text { Sampang } \\
\text { District }\end{array}$ & Sampang & 1,152 & 876,950 \\
\hline $\begin{array}{c}\text { Pamekasan } \\
\text { District }\end{array}$ & Pamekasan & 733 & 795,526 \\
\hline $\begin{array}{c}\text { Sumenep } \\
\text { District }\end{array}$ & Sumenep & 1,147 & $1,041,915$ \\
\hline
\end{tabular}

The relationship between the four regencies in Madura Island is currently in the context of establishing cooperation in the field of Madura tobacco farming. This relationship was established to improve the welfare of tobacco farmers. This collaboration is expected to increase tobacco production in each region of Madura which according to BPS East Java data has decreased. The positive effects of this partnership are very much from increasing the welfare of tobacco farmers, increasing tobacco production and can eradicate price discrimination by the tobacco mafia (middlemen / collectors and others). 
Dzikrillah Thoriqur Rahman, Retno Sunu Astuti; Collaboration between Regencies in ... |503

Collaboration between Regencies in Fulfilling Rajangan Madura National Tobacco Production is establishing inter-regional cooperation using 5 elements of intergovernmental relations, including 1) The role of government, 2) Interaction of public officials, 3) Sustainable communication, 4) The role of administrators, 5) focus on policy. In addition, it will explain the factors that cause a decline in Madura Tobacco Cracks production every year.

\section{Collaboration between Regencies in Fulfilling the National Production of Rajangan Madura Tobacco}

Madura is an archipelago in the administrative area of East Java Province. In Madura Island, the majority of the community's work is farming, where most people become tobacco, salt and rice farmers. So it is not surprising that the island of Madura is famous for the salt islands and the land of green gold. The term has been named because the Madura region is also the largest tobacco producer in the archipelago of the Dutch colonial era. In addition, Madura Island is also the center of the kretek cigarette factory and when the tobacco harvest season arrives, the factory in the Madura region competing to get tobacco that has been processed by farmers.

Madura tobacco is also an admired variant of its taste, aroma and purity. Madura tobacco farmers maintain their authenticity without a mixture of tobacco from other regions. This is what makes Madura tobacco superior to other tobacco. In fulfilling this national production, Pamekasan Regency certainly cannot stand alone even though Pamekasan regency is the largest tobacco producer in East Java Province, which every year tobacco production can penetrate approximately 18 tons. The Madura region, which consists of the four districts, can be seen from the total production data in 2017 that reached 43 tons.

It's just that the resulting production still does not meet market needs. So Pamekasan Regency must establish cooperation between Regencies in Madura to be able to jointly increase Madura tobacco production. With this increase in production, it will have a good impact on the Local Revenue (PAD) in each Regency and can also improve the welfare of tobacco farmers through the cooperation established. To see how the cooperation between regencies in Madura can be seen from how intergovernmental relations works. This can be seen with the 5 key elements of intergovernmental relations expressed by Wright (1974) in (Irawanto et.al, 2015). The following explanation.

1) The role of goverments,

This aspect emphasizes the relationship between government units in each region. Increased Madura tobacco production involves four regencies on Madura Island, namely Bangkalan Regency, Sampang Regency, Pamekasan Regency and Sumenep Regency. In this collaboration each regency has its own role in its own area. With this role in cooperation, every district needs to have a basis for regulation and support from the relevant government agencies / institutions, namely the Industry and Trade Office. Pamekasan Regency is the initiator of the collaboration for Madura Tobacco Production Increase.

The aim of this collaboration is for Madura to remain the largest tobacco supplier in Indonesia with superior quality and quantity. The benefits that will be felt for each Regency in this collaboration are a) Improving tobacco farmers, b) Increasing Local Original Income (PAD) in Madura Tobacco farming and, c) Minimizing the movement of tobacco mafia (cukong / collectors) which has caused a decrease in prices among the Madurese the farmer. 


\section{Jurnal Ilmiah Ilmu Administrasi Publik: Jurnal Pemikiran dan Penelitian Administrasi Publik \\ Volume 10 Number 2, July-December 2020. Page 497-507}

The cooperation of the four regencies will definitely be felt by each element, although the methods applied between regions in fulfilling tobacco production have differences. In addition, the Government of Pamekasan Regency provided input to the three Regencies that would strengthen this collaboration on the existence of the Madura Tobacco Regulation, with the regulations relating to Madura Tobacco would provide convenience in achieving the objectives of the collaboration.

In this regulation the main objective is to improve the welfare of tobacco farmers and to make Madura Tobacco a leading commodity in the region.

2) The intrection of public officials,

The interaction of public officials in terms of cooperation between regions is important because it will determine the continuation of cooperation. The interaction is seen from four sub elements, namely the behavior, beliefs, perceptions and preferences of the apparatus involved. The following is an overview of each sub element:

a) Behavior

This aspect shows the attitude of officials from each party involved in cooperation. The attitude of officials from each district government on the island of Madura showed an optimistic attitude to success in meeting the production of Madura tobacco in each district area.

b) Trust

Trust is the most important aspect in establishing cooperation. This collaboration was established with mutual trust between district governments. This is evident in the accountability of each party in carrying out its roles and obligations to the farmers of temabakau.

c) Perception

This aspect is to see the understanding of each party about the importance of interregional cooperation in meeting the national production of Rajangan madura tobacco. Each local government sees that progress in the agriculture sector will increase the PAD of each district government and can prosper the tobacco farmers.

d) Preference

The preference aspect shows the tendency of each party involved in cooperation. The preference for each Regency involved in the collaboration is to preserve and cultivate native Madura tobacco plants as regional superior commodities.

\section{3) Sustainability communications,}

Communication between regional officials in cooperation is very important. Interactions carried out between Regency officials regularly indicate ongoing communication. When viewed from the frequency of communication, inter-regional cooperation in meeting the national production of Madura Rajangan Tobacco has been carried out routine communication with meetings through certain scheduling conducted by the Pamekasan Regency Industry and Trade Office where the meeting place is often scheduled at the Regional Coordinating Board (BAKORWIL) of Pamekasan Regency. 
Dzikrillah Thoriqur Rahman, Retno Sunu Astuti; Collaboration between Regencies in ... $\mid 505$

4) The roles of administrastor,

The implementation of inter-regional cooperation in the fulfillment of the Rajangan Madura Tobacco National Production is inseparable from the role of executive and legislative officials. The role of executive officials at the regional level is a key actor in implementing cooperation. This was apparent in the executive agency which had given the mandate to the head of the department to collaborate so that the collaboration could continue. While the legislative role is related to the budget used in carrying out cooperation. That is because the budgeting function is in the hands of the legislature so that the budget due to this collaboration must obtain legislative approval.

In addition, the duties of the legislature for regions that do not yet have regulations on Madura Tobacco must be formulated first so that in regional policies in preserving and cultivating native Madura tobacco plants as superior commodities in this region there is a legal umbrella and can run well on the cooperation carried out.

5) Focus on the policy.

Every program and activity for the fulfillment of Rajangan Madura Tobacco National Production is sourced from each of the parties involved. In the implementation of cooperation, each party does not make a budget allocation that is specific to cooperation, but each Regency formulates each budget that must be provided in the fulfillment program of Madura tobacco production.

In the interwoven collaboration between the regencies on Madura Island, it only discusses ways or solutions so that Madura remains the largest tobacco producer in the national scope and by fulfilling this production can attract many manufacturers to work together to buy tobacco from farmers, so that farmers' welfare is guaranteed.

\section{Factors Causing the Declining Production of Farmers in Producing Tobacco Rajangan Madura}

With the study of literature and observations directly related to Madura tobacco, which is a factor causing the decline in farmers' production in producing Rajangan Madura tobacco, among others, are as follows:

First, falling tobacco prices are a major factor for farmers in producing tobacco. Farmers feel disadvantaged because what is their hope of being able to get a big profit in tobacco farming again disappears because of the price game made by collectors or cukong.

Second, climate factors also affect the maturation process of tobacco until it is ready to harvest. If during the tobacco season is decorated with high rainfall it will affect the quality of tobacco, not only that the factory will be reluctant to buy Madura tobacco from farmers or collectors.

Third, the reduction in land owned by the government and the community caused by the fulfillment of the development of local government infrastructure such as parks, official offices, soccer fields, activating the Madura airport land and other public facilities. For land owned by farmers due to the construction of community settlements (housing) and the conversion of land 


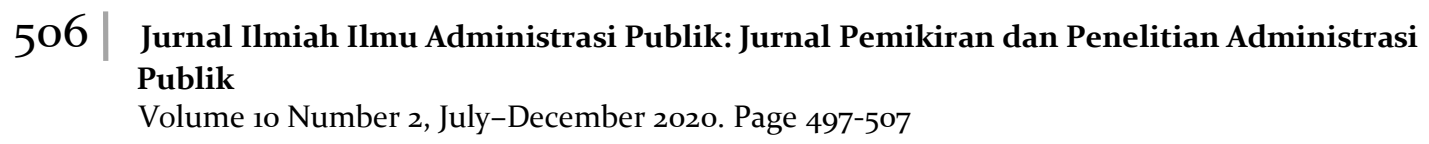

functions which all plantation land (rice fields) becomes a center for shops, home factories and others.

The three factors above related to the decline in Madura tobacco production were analyzed by researchers through observation, interviews and conducting a literature study.

\section{CONCLUSION}

Collaboration between Madura regencies in the agricultural sector in fulfilling the national production of Rajangan madura tobacco can be concluded that the intertwined relationships between regions involved in cooperation are carried out by dividing the roles of their respective regions. Interaction of public officials shows cooperation in behavior, beliefs, perceptions and preferences.

Regarding the communication developed from the four regions, looking for ways and solutions to be able to increase Madura tobacco production in each regency, besides solving the problems faced in each year, which are related to the price of tobacco, Rajangan Madura which often plummeted, due to the game of collectors.

A meeting of public officials / related offices can exchange ideas and ideas to give good things to the agricultural sector, especially Madura tobacco. For the successful fulfillment of Rajangan Madura Tobacco National Production, a Memorandum of Understanding (MoU) was made regarding the fulfillment of Madura Tobacco National Production as well as cultivating Madura tobacco plants as regional superior commodities so that it can improve the welfare of farmers, traders and local income.

\section{REFERENCES}

\section{Book :}

Djaja, dkk. (2018). Peningkatan Produksi dan Mutu Tembakau Madura Melalui Inovasi Teknologi dan Dukungan Kebijakan. Jakarta. IAARD Press.

Nasir, Muhammad. (2012). Metode Penelitian. Jakarta. Ghalia Indonesia.

Hamzah, Amir. (2017). PTK Qualitative Quantitatif atau Mixed. Yogyakarta. Deepublish.

Irawanto, et.al. (2015). "Intergovernmental Relations and Dilema of the Cooperation". Journal of Basic Applied Scientific Research Volume 5(8): 76-85.

Miles, M. ., Huberman, A. ., \& Saldana, J. (2014). Qualitative Data Analysis, A Methods Sourcebook (3rd ed.; Tjetjep Rohindi Rohidi, ed.). Jakarta: UI-Press.

Nasir, Muhammad. (2012). Metode Penelitian. Jakarta. Ghalia Indonesia

Peraturan Daerah No 4 Tahun 2015 Tentang Tata Niaga,Budidaya dan Perlindungan Tembakau Madura.

Undang-undang Nomor 23 Tahun 2014 Tentang Pemerintah Daerah

\section{Journal :}

Fauziyah, E. (2010). Pengembangan Pertanian pada Daerah Sentra Produksi Tembakau di Kabupaten Pamekasan. Jurnal Embryo 7(2): 117-179. Fakultas Pertanian. Universitas Trunojoyo. 
Dzikrillah Thoriqur Rahman, Retno Sunu Astuti; Collaboration between Regencies in ... $\mid 507$

Hammam, Rezza Harits. (2015). Proses Pemasaran Hasil Pertanian Tembakau (Studi Kasus Pada Proses Pemasaran Hasil Pertanian Tembakau Di Desa Mandisari Kecamatan Parakan Kabupaten Temanggung). Universitas Negeri Yogyakarta.

Hasan, Fuad dan Dwijono Hadi Darwanto. (2013). Prospek dan Tantangan Usaha Tani Tembakau Madura. Jurrnal SEPA10(1): 63-70. Universitas Trunojoyo Madura.

Handaka, Tatag \& Surokim. (2015). Pola Komunikasi Kelompok Petani Tembakau Madura sebagai Basis Penyusunan Kebijakan Pemberdayaan Ekonomi Politik. Jurnal Ilmu Komunikasi. 10(7): 67-88.

Hakim, Nurul Fatwa \& Gunawan Wibisono. (2017). Social Capital of Tobacco Farmer for Social Welfare Improvement. Jurnal PKS. 16(4): 369-380.

Lubis, Hisnuddin. (2012). Ketidakberdayaan Petani Tembakau Madura Dalam Tataniaga Tembakau Madura (Study Di Kabupaten Pamekasan). Jurnal Agro Ekonomi. 26(1) 90121.

Nurwiyati, Riris Tri Dan Yuwanto. (2017). Peran Asosiasi Petani Tembakau Indonesia (APTI) Dalam Memperjuangkan Kepentingan Petani Tembakau Di Kabupaten Temanggung. Universitas Diponegoro Semarang.

Santoso, Thomas. (2012), Tataniaga Tembakau Di Madura. Jurnal manajemen dan kewirausahaan. 3(2): 96 - 105, Universitas kriten Petra.

\section{Website :}

Badan Pusat Statistik. (2015).Produksi, Produktivitas, dan Luas Areal Tanaman Perkebunan Tembakau Menurut Kecamatan di Kabupaten Pamekasan 2015. Diakses dari Https://pamekasankab.bps.go.id/statictable/2017/06/09/238/produksi-produktivitas-danluas-areal-tanaman-perkebunan-tembakau-menurut-kecamatan-di-kabupaten-pamekasan2015.htm 